\title{
Anti-atherosclerotic function of Astragali Radix extract: downregulation of adhesion molecules in vitro and in vivo
}

Yang You ${ }^{1,2}$, Yan Duan ${ }^{1}$, Shao-wei Liu', Xiao-lin Zhang ${ }^{1}$, Xiu-li Zhang ${ }^{3}$, Jia-tao Feng ${ }^{3}$, Cheng-hui Yan ${ }^{1}$ and Ya-ling $\operatorname{Han}^{1,4^{*}}$

\begin{abstract}
Background: Atherosclerosis is considered to be a chronic inflammatory disease. Astragali Radix extract (ARE) is one of the major active ingredients extracted from the root of Astragalus membranaceus Bge. Although ARE has an anti-inflammatory function, its anti-atherosclerotic effects and mechanisms have not yet been elucidated.

Methods: Murine endothelial SVEC4-10 cells were pretreated with different doses of ARE at different times prior to induction with tumor necrosis factor (TNF)-a. Cell adhesion assays were performed using THP-1 cells and assessed by enzyme-linked immunosorbent assay, western blotting and immunofluorescence analyses to detect the expression of vascular cell adhesion molecule-1 (VCAM-1), intercellular adhesion molecule-1 (ICAM-1), phosphorylated inhibitor of $\mathrm{kB}(\mathrm{p}-\mathrm{i} \mathrm{kB})$ and nuclear factor (NF)-kB. We also examined the effect of ARE on atherosclerosis in the aortic endothelium of apolipoprotein E-deficient $\left(\mathrm{apoE}^{-/-}\right)$mice.
\end{abstract}

Results: TNF-a strongly increased the expression of VCAM-1 and ICAM-1 accompanied by increased expression of p-ikB and NF-KB proteins. However, the expression levels of VCAM-1 and ICAM-1 were reduced by ARE in dose- and time-dependent manners, with the strongest effect at a dose of $120 \mu \mathrm{g} / \mathrm{ml}$ incubated for $4 \mathrm{~h}$. This was accompanied by significantly decreased expression of $\mathrm{p}-\mathrm{ikB}$ and inhibited activation of NF-kB. Immunofluorescence analysis also revealed that oral administration of ARE resulted in downregulation of adhesion molecules and decreased expression of macrophages in the aortic endothelium of apoE ${ }^{-/-}$mice. ARE could suppress the inflammatory reaction and inhibit the progression of atherosclerotic lesions in $\mathrm{apoE}^{-/-}$mice.

Conclusion: This study demonstrated that ARE might be an effective anti-inflammatory agent for the treatment of atherosclerosis, possibly acting via the decreased expression of adhesion molecules.

Keywords: Astragali Radix extract, Vascular cell adhesion molecule-1, Vntercellular adhesion molecule-1, Apolipoprotein E-deficient mice, Atherosclerosis

\section{Background}

Atherosclerosis is one of the most prevalent diseases in the world and is characterized by multifactorial and multistep processes. Atherosclerosis is known to be a chronic inflammatory disease, although its pathophysiological mechanisms remain elusive [1]. The adhesion of circulating leukocytes to the endothelium is an important cellular

\footnotetext{
* Correspondence: yalinghan@gmail.com

'Department of Cardiology, Cardiovascular Research Institute, Shenyang Northern Hospital, Shenyang, China

${ }^{4}$ Department of Cardiology, Shenyang General Hospital, 83 Wenhua Road, Shenyang 110840, China

Full list of author information is available at the end of the article
}

response to inflammation. Endothelial cells express an array of adhesion molecules that mediate the process of leukocyte attachment to the vascular wall during inflammation [2]. Leukocyte-endothelium interactions require regulation of the expression of various adhesion molecules by endothelial cells, such as vascular cell adhesion molecule-1 (VCAM-1) and intercellular adhesion molecule-1 (ICAM-1) [3]. Proinflammatory mediators such as interleukin-1 and tumor necrosis factor (TNF)- $\alpha$ can promote the activation of endothelial cells in the early stages of the inflammatory process. Activation on endothelial cells results in increased expression of VCAM-1 and ICAM-1

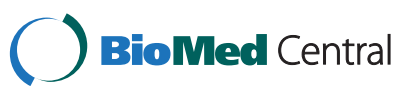


on their surfaces, causing leukocytes to adhere to the endothelium at local sites of inflammation [4], and ultimately resulting in the development of atherosclerosis. Various inflammatory pathways have been implicated in atherosclerosis, leading not only to the recruitment and entry of inflammatory cells into the arterial wall, but also to modification of the morphology and composition of atherosclerotic plaques. Certain inflammatory pathways, such as those involving VCAM-1, and ICAM-1, appear to play an important role in lesion initiation [5-7].

The root of Astragalus membranaceus Bge is a common Chinese medicinal herb. Several compounds isolated from this plant, as well as the plant itself, have been reported to show therapeutic potential in some diseases, such as nephropathy, cardiac contractile dysfunction and open wounds [8-10], and the root of A. membranaceus Bge was been widely used for the treatment of cardiovascular diseases in ancient China. Astragali Radix extract (ARE) is one of the major active ingredients extracted from the root of A. membranaceus Bge. Previous studies showed that ARE had potential anti-inflammatory activity [9,11-14], and recent evidence demonstrated that ARE could reduce macrophage migration [15] and adhesion to endothelial cells, and relieve local inflammation via a nuclear factor (NF)- $\mathrm{kB}$ pathway [16-19]. However, the anti-atherosclerotic effects of ARE and its mechanisms have not yet been elucidated.

The present study therefore aimed to clarify the antiatherosclerotic effects and molecular mechanisms of ARE by investigating its effects on the expression of adhesion molecules in murine endothelial cells stimulated with TNF- $\alpha$, investigating its influences on the NF-kB pathway, and assessing the progression of atherosclerotic lesions and the expression of adhesion molecules in the aortic endothelium of ARE-treated apolipoprotein E-deficient $\left(\right.$ apoE $\left.^{-/-}\right)$mice.

\section{Materials and methods Reagents}

ARE was provided by the Dalian Institute of Chemical Physics, Chinese Academy of Sciences (Dalian, China), and dissolved and diluted in incubation medium to yield final concentrations of $30-120 \mu \mathrm{g} / \mathrm{ml}$. TNF- $\alpha$ was purchased from Sigma-Aldrich (Saint Louis, MO, USA). Goat monoclonal anti-VCAM-1, goat monoclonal anti-ICAM-1, mouse monoclonal NF- $\mathrm{B}$ p 65 , mouse monoclonal phosphorylated inhibitor of $\kappa B(p-i \kappa B)-\alpha$, goat polyclonal Lamin $B$ and anti- $\beta$-actin antibodies were purchased from Santa Cruz (CA, USA). Rat anti-mouse Mac3 and rat anti-mouse CD31 antibodies were purchased from BD Pharmingen (San Diego, CA, USA). The mouse soluble VCAM-1 immunoassay and mouse soluble ICAM-1 immunoassay kits were purchased from R\&D Systems (MN, USA). The enhanced chemiluminescence (ECL) western blotting system was from Amersham Biosciences (Buckinghamshire, UK).

\section{Endothelial cell culture and treatment}

The murine endothelial cell line (SVEC4-10) was purchased from the American Type Culture Collection (MD, USA) and cultured in DMEM supplemented with $10 \%$ fetal calf serum (FCS, HyClone, UT, USA), $30 \mu \mathrm{g} / \mathrm{ml}$ endothelial cell growth factor (Sigma-Aldrich, Saint Louis, MO, USA), $5 \mathrm{U} / \mathrm{ml}$ heparin, $100 \mathrm{U} / \mathrm{ml}$ penicillin, and $100 \mathrm{U} / \mathrm{ml}$ streptomycin at $37^{\circ} \mathrm{C}$ in an atmosphere of $5 \% \mathrm{CO}_{2}$ and $95 \%$ air. The phenotype of SVEC cells was confirmed morphologically and by positive immunofluorescence staining of CD31. Cells were treated with 30, 60, or $120 \mu \mathrm{g} / \mathrm{ml} \mathrm{ARE}$ in fresh serum-free medium and incubated for $2,4,6$, or $8 \mathrm{~h}$.

\section{Culture of THP-1 cells}

THP-1 cells were purchased from the American Type Culture Collection and grown in RPMI-1640 media (Sigma) containing $10 \% \mathrm{FCS}, 100 \mu \mathrm{g} / \mathrm{ml}$ streptomycin, $100 \mathrm{IU} / \mathrm{ml}$ penicillin, $250 \mathrm{ng} / \mathrm{ml}$ fungizone, $1 \mathrm{mM}$ glutamine, $5 \times 10^{-5} \mathrm{M}$ 2-mercaptoethanol, and routinely subcultured three times per week at a ratio of 1:5.

\section{Mice}

Male apoE $\mathrm{E}^{-1-}$ mice $(\mathrm{n}=24$, age 8 weeks, $18-20 \mathrm{~g})$ on a C57BL/6 J background were obtained from the Department of Laboratory Animal Science, Peking University Health Science Center, China. All mice were barrier housed, specific pathogen-free, and maintained in static microisolator cages. Mice were fed a high-fat, high-cholesterol diet containing $15 \%$ fat and $0.25 \%$ cholesterol. $\mathrm{ApoE}^{-/-}$mice were randomized into either a control group or an ARE group ( $n=12$ for each group). ARE mice were given oral doses of ARE ( $5 \mathrm{~g} / \mathrm{kg}$ body weight per day). Blood and tissues were collected at 24 weeks of age for further analysis. The care and use of animals were performed in adherence with the National Institutes of Health Guidelines, and all experimental procedures involving animals were approved by the Ethics Committee of Shenyang Northern Hospital.

\section{Adhesion assay for THP-1 cells}

SVEC cells were plated in six-well plates and allowed to grow to confluence, as described above. The medium was removed and the cells were then incubated with $1.0 \mathrm{ml} /$ well DMEM medium containing $10 \%$ FCS with or without TNF- $\alpha(10 \mathrm{ng} / \mathrm{ml})$ or TNF- $\alpha$ plus ARE at the concentrations and incubation times indicated above. Culture supernatant was removed from the treated cells at the indicated time points, and the cells were gently washed three times with DMEM medium. A volume of $1.0 \mathrm{ml}$ of RPMI-1640 media containing $1 \times 10^{6}$ THP- 1 cells was then added to the endothelial cell monolayers 
in each well. The binding phase of the assay was performed at $37^{\circ} \mathrm{C}$ in a $5 \% \mathrm{CO}_{2}$ atmosphere for $15 \mathrm{~min}$ for THP-1 cells. Thereafter the wells were washed three times with phosphate-buffered saline (PBS) $(1.0 \mathrm{ml} /$ well), and all wells were examined under a microscope to determine if any loss of endothelial cells had occurred during incubation or washing. The number of THP-1 cells washed in PBS was counted using a counting slide. Experiments were performed in triplicate.

\section{Enzyme-linked immunosorbent assay (ELISA)}

Aliquots of culture medium were collected from cells treated as described above. VCAM-1 and ICAM-1 levels in the culture medium were measured directly using an ELISA kit (R\&D Systems), according to the manufacturer's instructions. Standards containing known amounts of recombinant VCAM-1 and ICAM-1 were also analyzed. ELISA assay results were measured using a microplate reader. Absorbance was measured spectrophotometrically at $450 \mathrm{~nm}$ and plotted against a standard curve with VCAM-1 and ICAM-1 levels expressed in ng/ml. Experiments were performed in triplicate.

\section{Western blot analysis}

Confluent cells were cultured in medium with or without TNF- $\alpha(10 \mathrm{ng} / \mathrm{ml})$ or TNF- $\alpha$ plus ARE at the concentrations and the incubation times indicated above to detect VCAM-1, ICAM-1, NF-kB, and p-ikB. Total proteins were extracted with $100 \mu \mathrm{l}$ of lysis buffer $(50 \mathrm{mmol} / \mathrm{l}$ Tris, $10 \mathrm{mmol} / \mathrm{l} \mathrm{MgCl}_{2}, 0.5 \mathrm{~mol} / \mathrm{l} \mathrm{NaCl}, 1 \%$ Triton $\mathrm{X}$-100) supplemented with a protease inhibitor mixture and $1 \mathrm{mmol} / \mathrm{l}$ phenylmethylsulfonyl fluoride. Cells were maintained on ice and lysates were harvested by scraping. The supernatants were collected after centrifugation at $14,000 \mathrm{~g}$ for $10 \mathrm{~min}$. For nuclear protein analysis, cells were resuspended in hypotonic buffer on ice and detergent was added to $0.5 \%$. Nuclei were pelleted and resuspended in nuclear protein extract buffer $(50 \mathrm{mmol} / \mathrm{l}$ HEPES [pH 7.8], $300 \mathrm{mmol} / \mathrm{l} \mathrm{NaCl}, 50 \mathrm{mmol} / \mathrm{l} \mathrm{KCl}$, $0.1 \mathrm{mmol} / \mathrm{l}$ EDTA, $10 \%$ [v/v] glycerol) on ice for $30 \mathrm{~min}$ and then spun, and the supernatant was saved. Protein levels in the supernatant were determined using the BCA method. Aliquots of $30 \mu \mathrm{g}$ of each protein sample were resolved by $10 \%$ sodium dodecyl sulfate polyacrylamide-gel electrophoresis and transferred to a polyvinylidene fluoride membrane. After transfer, membranes were blocked with $5 \%$ nonfat dry milk in Tris-buffered saline and then incubated overnight with primary antibodies at $4^{\circ} \mathrm{C}$. After washing, blots were further incubated with 1:2,000 diluted secondary antibodies including horseradish peroxidase (HRP)-conjugated goat anti-mouse, goat anti-rabbit, or rabbit anti-goat IgG for $2 \mathrm{~h}$ at room temperature. After additional washing, HRP activity was detected by ECL, according to the manufacturer's instructions.

\section{Quantitation of arterial atherosclerotic lesions}

The proximal aortas of apoE $\mathrm{E}^{-/-}$mice were immersed in ice-cold $4 \%$ paraformaldehyde for $30 \mathrm{~min}$. The samples were then transferred to $30 \%$ sucrose-PBS solution at $4^{\circ}$ $\mathrm{C}$ for $24 \mathrm{~h}$, embedded in tissue freezing medium and snap-frozen in liquid nitrogen. Cryosections (5 $\mu \mathrm{m}$ thick) were cut from the proximal aortas beginning at the end of the aortic sinus, and stained with oil red $\mathrm{O}$ and hematoxylin and eosin. Arterial atherosclerotic lesions were also measured in aortas by en face oil red $\mathrm{O}$ staining. Quantitative analysis of the lesions was performed using Image Pro Plus software on at least 15 sections from each animal by an operator who was blinded to group assignment.

\section{Immunofluorescence staining}

SVEC cells were plated on coverslips and incubated at $37^{\circ} \mathrm{C}$ and $5 \% \mathrm{CO}_{2}$ to allow the cells to adhere and spread. Serial $5-\mu$ m-thick cryosections were cut from the proximal aortas. Cells or cryosections were fixed with $4 \%$ paraformaldehyde for $20 \mathrm{~min}$. After washing three times with PBS, cells or cryosections were permeabilized with $1 \%$ Triton X-100 in PBS for 30 min and blocked with goat serum for $20 \mathrm{~min}$ at room temperature. The cells were stained with primary antibodies against NF$\kappa \mathrm{B}$. The cryosections were incubated with primary antibodies to VCAM-1, ICAM-1 or Mac-3. Alexa Fluor 488, 555 , and 568 secondary antibodies (Invitrogen, OR, USA) were used at concentrations of 1:300. Nuclei were stained with 4',6-diamidino-2-phenylindole (DAPI). Stained cells or tissues were observed using the Leica QWN (Wetzlar, Germany) analysis system.

\section{Assessment of cell viability}

The 3-(4,5-dimethylthiazol-2-yl)-2,5-diphenyltetrazolium bromide (MTT; Sigma-Aldrich, Saint Louis, MO, USA) assay is based on the cleavage of MTT by mitochondrial dehydrogenases, reflecting the cell viability. SVEC cells were treated with $10 \mathrm{ng} / \mathrm{ml} \mathrm{TNF- \alpha}$ in the absence or presence of ARE (30, 60 or $120 \mu \mathrm{g} / \mathrm{ml}$ ) for $8 \mathrm{~h}$, followed by the addition of $0.5 \mathrm{mg} / \mathrm{ml}$ MTT medium and incubation for $4 \mathrm{~h}$ at $37^{\circ} \mathrm{C}$. The medium was removed and dimethyl sulfoxide was added. The absorbance was examined at $570 \mathrm{~nm}$.

\section{Statistical analysis}

The data are expressed as mean \pm SD. All data were analyzed using SPSS 13.0 statistical software. Differences between two groups were compared using unpaired Student's $t$-tests. Differences among three or more groups were compared using one-way analysis of variance 
(ANOVA). Statistical significance was defined as $\mathrm{P}<0.05$ (two-tailed).

\section{Results \\ ARE inhibits TNF-a-stimulated adhesion of THP-1 cells to SVEC cells}

The number of THP-1 cells adhering to the endothelial cell monolayer was increased by pretreatment with $10 \mathrm{ng} / \mathrm{ml}$ TNF- $\alpha$ for $4 \mathrm{~h}$. However, the TNF- $\alpha$-stimulated increase in leukocyte adhesion was reduced almost to control levels when SVEC cells were treated with $10 \mathrm{ng} /$ ml TNF- $\alpha$ together with $120 \mu \mathrm{g} / \mathrm{ml} \mathrm{ARE,} \mathrm{especially} \mathrm{after}$ 4-8 $\mathrm{h}$ (Figure $1 \mathrm{~A}$ and $\mathrm{B}$ ). The MTT assay was used to exclude the possibility of toxic effects induced by ARE (Figure 1C). ARE had no influence on cell viability at the concentrations used. These result demonstrate that the downregulation of adhesion molecules by ARE in SVEC cells was not a result of direct toxicity of the substance.

\section{ARE inhibits upregulation of VCAM-1 and ICAM-1 expression induced by TNF-a}

ELISA assays demonstrated that the expression levels of soluble VCAM-1 and soluble ICAM-1 in the supernatant from SVEC cells increased rapidly after exposure to TNF- $\alpha$ (10 ng/ml) (Figure 2A). Expression levels of VCAM- 1 and ICAM-1 induced by $10 \mathrm{ng} / \mathrm{ml}$ TNF- $\alpha$ were inhibited by co-incubation with different concentrations of ARE $(30,60$ or $120 \mu \mathrm{g} / \mathrm{ml})$ in a dosedependent manner. The TNF- $\alpha$-induced VCAM- 1 and ICAM-1 expression levels were inhibited by $61 \%$ and $67 \%$, respectively, by $120 \mu \mathrm{g} / \mathrm{ml}$ ARE. Preincubation of SVEC cells with $120 \mu \mathrm{g} / \mathrm{ml}$ ARE for 2, 4, 6, or $8 \mathrm{~h}$ resulted in inhibition of the TNF- $\alpha$-induced VCAM-1 and ICAM-1 expression levels in a time-dependent manner. Significant reductions in TNF- $\alpha$-induced VCAM-1 and ICAM-1 expression levels were seen in cells preincubated with ARE for 4-8 h. These results demonstrate that ARE inhibited the induction of VCAM- 1 and ICAM- 1 by TNF- $\alpha$ in dose- and timedependent manners.

Western blot analysis showed similar results regarding the levels of VCAM-1 and ICAM-1 protein expression. ARE dose-dependently inhibited the TNF- $\alpha$-induced increases in VCAM-1 and ICAM-1 protein levels; ARE $120 \mu \mathrm{g} / \mathrm{ml}$ completely abolished TNF- $\alpha$-induced upregulation of VCAM-1 and ICAM-1 (Figure 2B). Preincubation of SVECs with $120 \mu \mathrm{g} / \mathrm{ml}$ ARE for 2, 4, 6, or $8 \mathrm{~h}$ inhibited TNF- $\alpha$-induced VCAM- 1 and ICAM-1 expression levels in a time-dependent manner. Significant reductions in TNF- $\alpha$-induced VCAM-1 and ICAM-1 expression levels were seen in cells preincubated with ARE for 4-8 h (Figure 2C).

\section{ARE inhibits TNF-a-induced NF-KB activation}

To determine if ARE-induced inhibition of adhesionmolecule expression was mediated by blocking the $\mathrm{p}-\mathrm{i} \kappa \mathrm{B} / \mathrm{NF}-\kappa \mathrm{B}$ pathway, the total protein level of $\mathrm{p}-\mathrm{i} \kappa \mathrm{B}$ and the nuclear protein level of NF-kB p65 were analyzed by western blotting. The levels of $p-i \kappa B$ and NF- $\mathrm{NB}$ protein increased dramatically following induction by TNF- $\alpha(10 \mathrm{ng} / \mathrm{ml})$. Co-incubation of the cells with different concentrations of ARE at different times prevented $i \kappa B$ phosphorylation and NF- $\mathrm{B}$ activation in dose- and time-dependent manners. ARE almost completely abolished TNF- $\alpha$ - induced ikB phosphorylation and NF- $\mathrm{kB}$ activation after preincubation for $4-8 \mathrm{~h}$ at $120 \mu \mathrm{g} / \mathrm{ml}$ (Figure 3A and B). Furthermore, immunofluorescence staining demonstrated that ARE could inhibit TNF- $\alpha$-induced translocation of NF- $\kappa B$ to the nucleus. NF- $\mathrm{kB}$ was detected in the cytoplasm in untreated control cells or cells treated with ARE alone (Figure $3 \mathrm{C}$ ). However, rapid translocation of NF-kB from the cytoplasm to the nucleus occurred when the cells were incubated for $4 \mathrm{~h}$ with TNF- $\alpha(10 \mathrm{ng} / \mathrm{ml})$. This translocation was significantly inhibited by $120 \mu \mathrm{g} / \mathrm{ml}$ $\mathrm{ARE}$, and the nucleus remained virtually free of the transcription factor in cells treated with both TNF- $\alpha$ and ARE.

\section{ARE prevents atherosclerosis development in apoE $\mathrm{F}^{-/-}$ mice}

All apo: ${ }^{-/-}$mice fed a high-fat, high-cholesterol diet for 16 weeks developed atherosclerotic lesions along the proximal aortic walls and at the valve cusps. The intima was markedly thickened with the accumulation of lipids, macrophages and foam cells. However, ARE-treated mice showed a significant reduction in atheroscleroticplaque-lesion size compared with control mice. The ratio of plaque area to total vessel area in the ARE mice was $16.12 \pm 1.73 \%$ compared with $31.51 \pm 1.92 \%$ in control mice $(\mathrm{P}<0.01)$ (Figure $4 \mathrm{~A})$. In addition, en face oil red $\mathrm{O}$-stained aortas from apoE $\mathrm{E}^{-/-}$mice in both groups exhibited similar results (Figure 4B). Atherosclerotic lesions in the aortic root in the control and ARE-treated apoE $E^{-/-}$mice were immunostained with anti-mouse macrophage antibody (Mac-3). Macrophage infiltration into the endothelium was significantly inhibited in AREtreated apoE ${ }^{-/-}$mice $(21.34 \pm 1.82 \%)$ compared with control apoE ${ }^{-/-}$mice $(38.4 \pm 1.41 \%$ ) (Figure 4C).

\section{ARE decreases the expression of adhesion molecules in} the endothelium of apoE ${ }^{-/-}$mice

We investigated the effects of ARE on inflammatory responses to further clarify the molecular mechanisms whereby ARE restricts the development of atherosclerotic lesions. The levels of adhesion molecules in the 


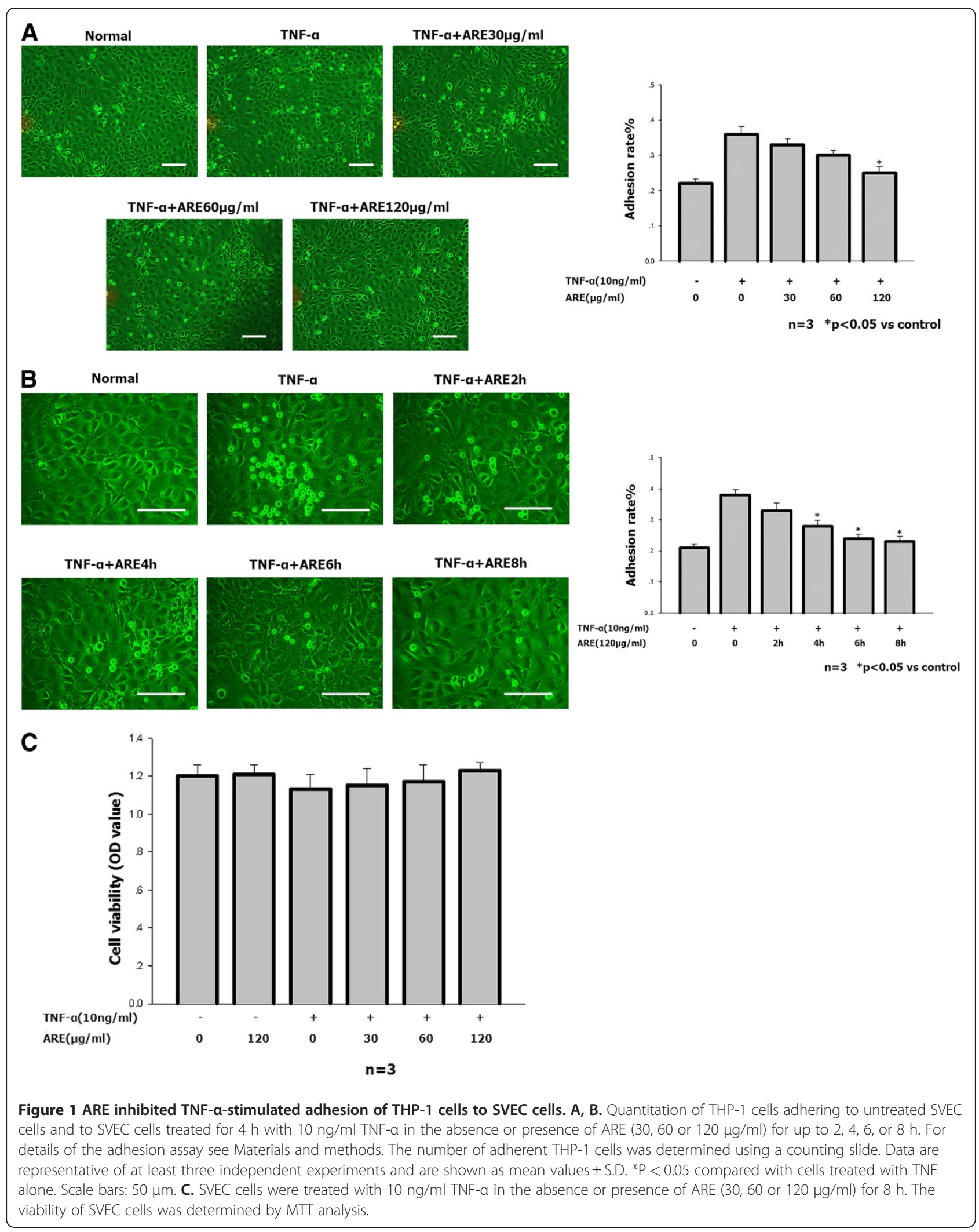




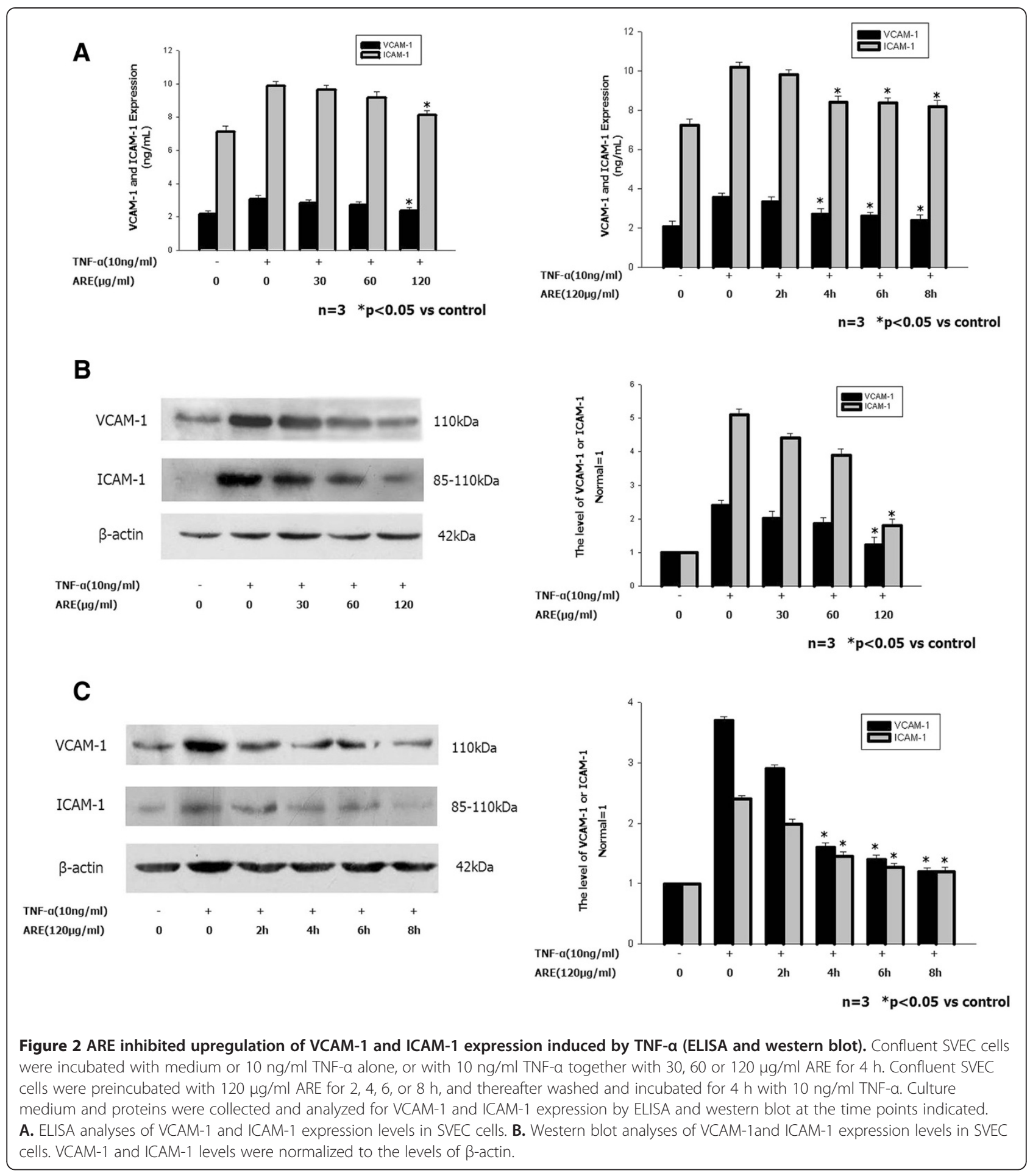

endothelium of apoE ${ }^{-/-}$mice were evaluated. Immunofluorescence analysis revealed reduced staining of VCAM-1 and ICAM-1 in aortic sections from ARE-treated $\mathrm{apoE}^{-/-}$mice. The relative fluorescence intensities of VCAM-1 and ICAM-1 in the endothelium of ARE-treated $\mathrm{apoE}^{-/-}$mice were significantly reduced (Figure 5). Staining for CD31 showed that the aortic endothelium remained intact in ARE-treated mice. These results suggest that ARE inhibited the interaction of inflammatory cells with endothelial cells.

\section{Discussion}

Multiple lines of evidence support the idea that atherosclerosis is a chronic inflammatory disease [1]. In China, 


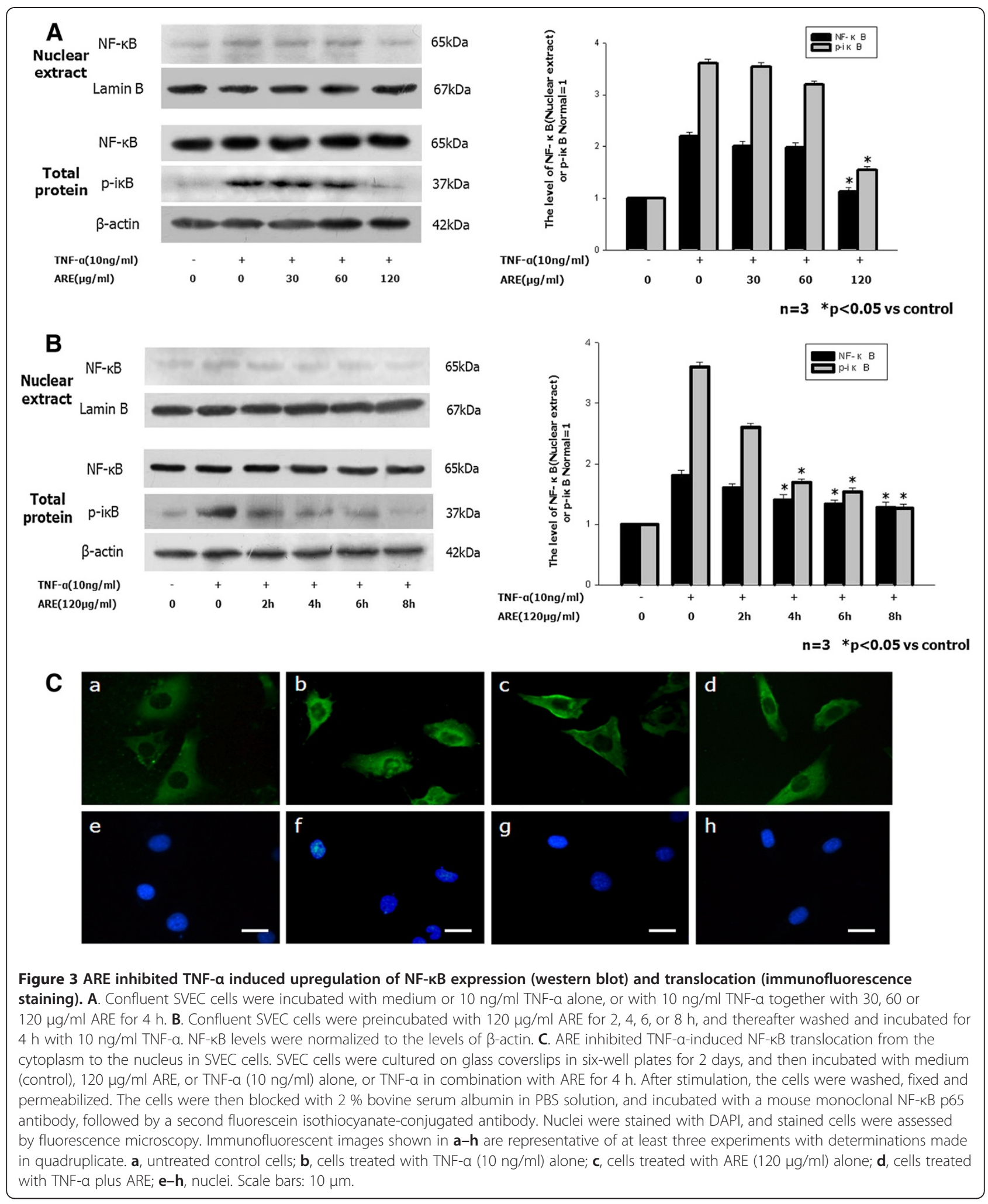

A. membranaceus Bge root has been widely used for the treatment of cardiovascular diseases [20,21], and ARE is one of the major active ingredients extracted from this root. Previous studies have revealed that ARE possesses anti-inflammatory and immunoregulatory roles [22]. Furthermore, recent evidence demonstrated that ARE could reduce macrophage migration [15] and adhesion to endothelial cells, and relieved local inflammation via the 


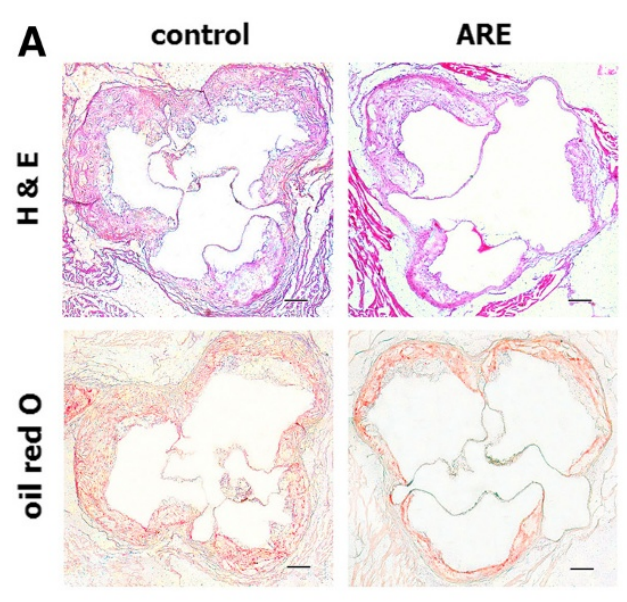

B
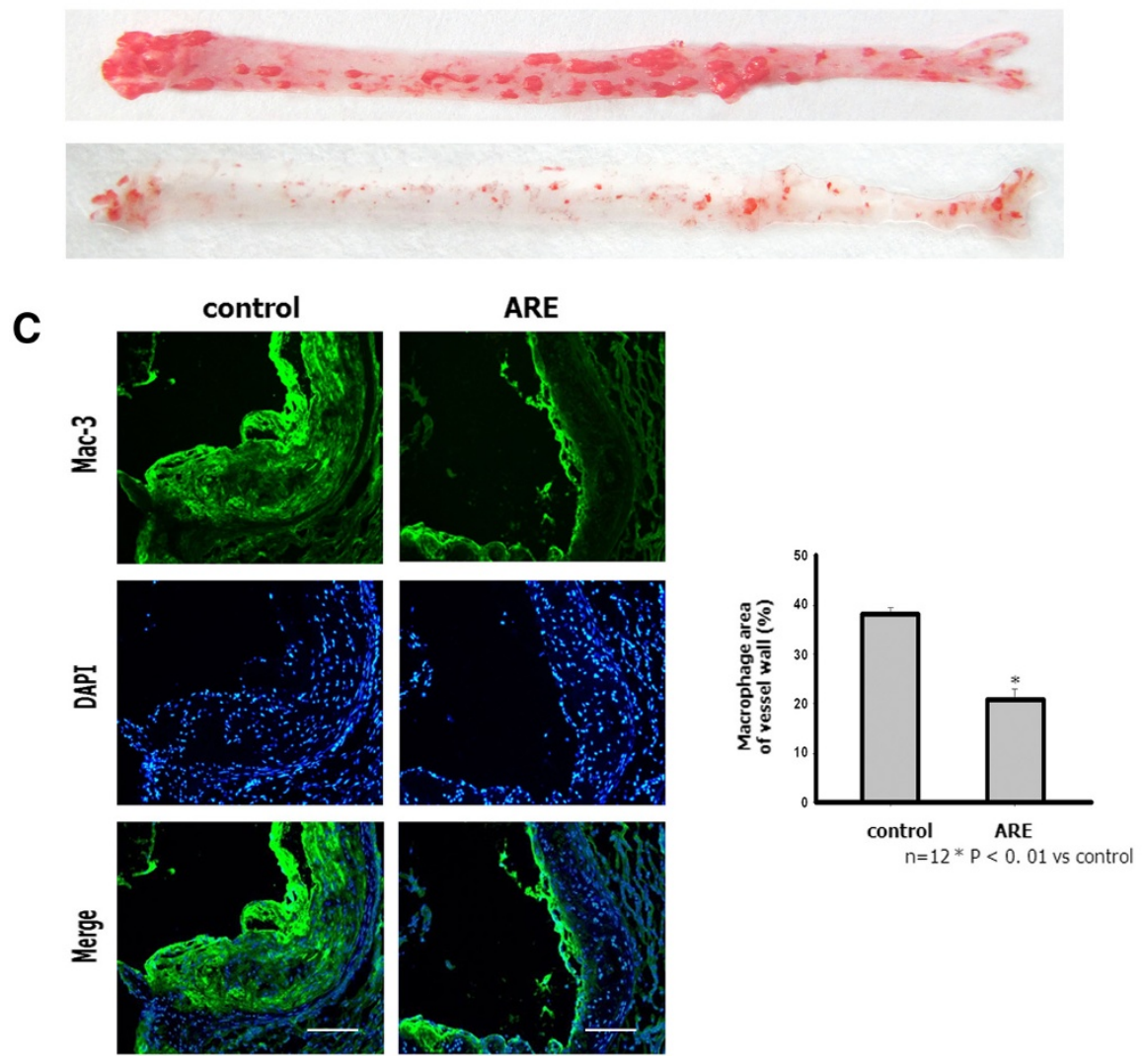

Figure 4 ARE inhibited progression of established atherosclerotic lesions and accumulation of macrophages in the aorta of apoE ${ }^{-/-}$ mice. A. Hematoxylin and eosin and oil red $\mathrm{O}$ staining of lesions in the aortic root in control and ARE apoE ${ }^{-/-}$mice $(100 \times)$. Scale bars: $80 \mu \mathrm{m}$. B. Representative oil red O-stained aortas from apoE ${ }^{-1-}$ mice in both groups. Bar graph shows distribution of intima/lumen ratio. ${ }^{*} \mathrm{P}<0.01 \mathrm{vs}$ control. C. Atherosclerotic lesions in aortic root from control and ARE apoE ${ }^{-1-}$ mice immunostained with anti-mouse macrophage antibody (Mac3). Double-immunofluorescence staining ( $n=4-5$ sections per tissue, at least three sites of analysis per slide). Bar graph shows quantitative comparison of composition of atherosclerotic lesions between control and ARE-treated groups. Scale bars: $80 \mu \mathrm{m}$.

NF-KB pathway [16-19]. We hypothesized that ARE might have anti-atherosclerotic properties associated with its anti-inflammatory role. We therefore investigated the effects of ARE on the expression of adhesion molecules and its anti-inflammatory effects in vitro and in vivo. ARE inhibited the activation of NF- $\mathrm{kB}$ in SVEC cells in vitro and reduced atherosclerotic-lesion size in $\mathrm{apoE}^{-1-}$ mice fed a high-fat, high-cholesterol diet in vivo. 

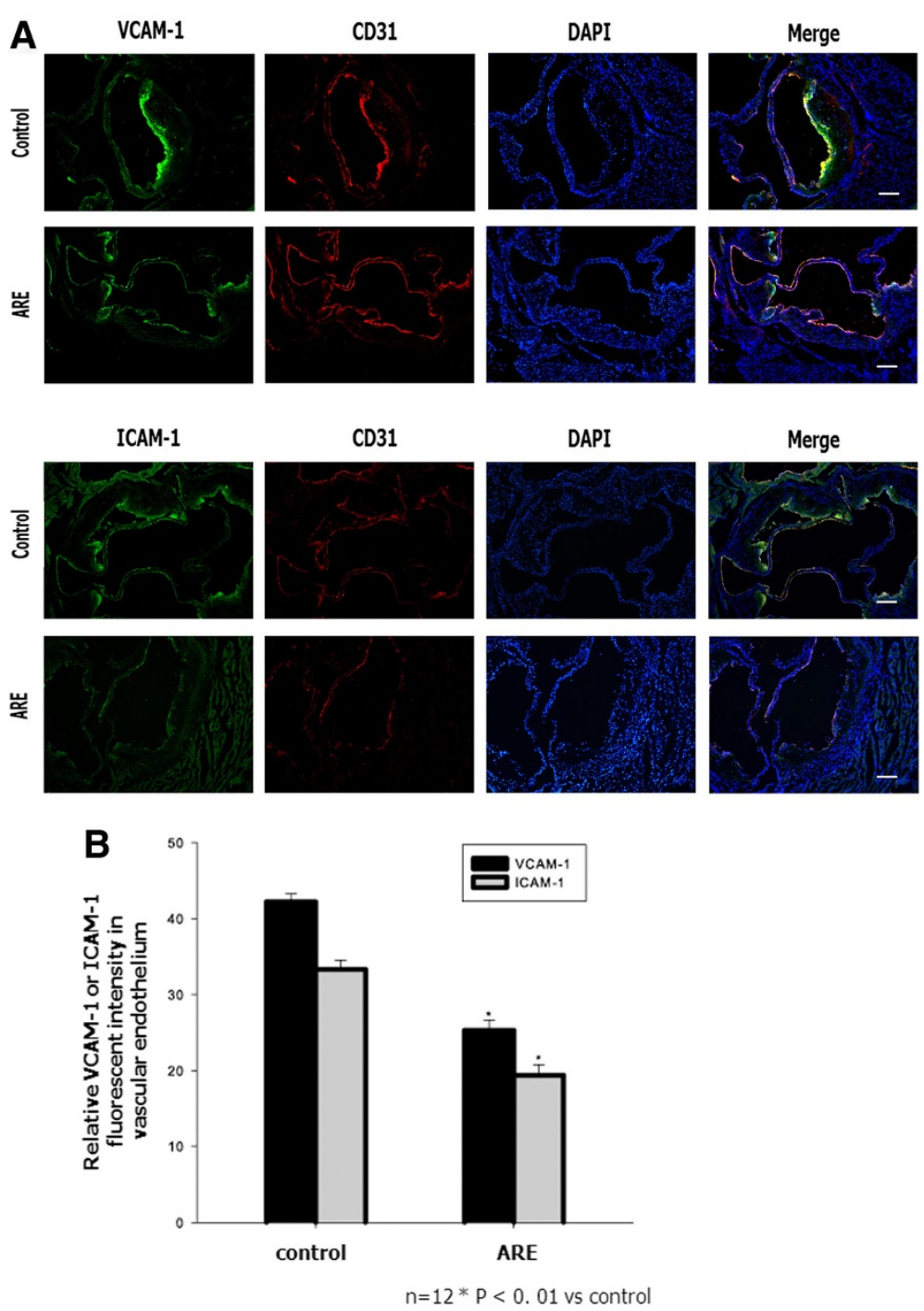

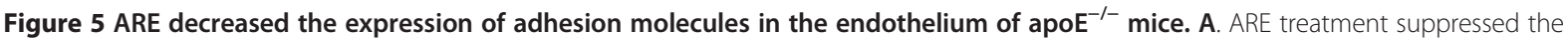
levels of VCAM-1 and ICAM-1 in the aortic endothelium of apoE ${ }^{-1-}$ mice. Double-immunofluorescence staining ( $\mathrm{n}=4-5$ sections per tissue, at least three sites of analysis per slide). B. The relative fluorescence intensity of VCAM-1 and ICAM-1 in the endothelium of apoE ${ }^{-/-}$mice. *P $<0.01$ vs control. Scale bars: $80 \mu \mathrm{m}$.

One of the initial steps in the inflammatory cascade is the expression of adhesion molecules in endothelial cells and the adhesion of circulating leukocytes to the activated endothelium $[23,24]$. The current study found that pretreatment of SVEC cells with ARE almost abolished TNF- $\alpha$-induced adhesion of monocytic THP-1 cells to endothelial cells. ARE could reduce TNF- $\alpha$-induced upregulation of VCAM-1 and ICAM-1 expression levels in dose- and time-dependent manners, suggesting that ARE might be able to block leukocyte adhesion in vitro completely. Co-treatment of SVEC cells with TNF- $\alpha$ and ARE resulted in dose- and time-dependent decreases in adhesion molecules accompanied by a significant decrease in $\mathrm{p}-\mathrm{i} \kappa \mathrm{B}$ expression and inhibition of $\mathrm{NF}-\mathrm{\kappa} \mathrm{B}$ activation. NF- $\mathrm{kB}$ binds to specific sites in the promoter region of target genes and apparently mediates TNF- $\alpha$ induced activation of endothelial cells by transiently inducing the genes coding for adhesion molecules [25,26] and atherosclerosis [27-31]. ARE dose- and time-dependently inhibited TNF- $\alpha$-induced upregulation of NF- $k B$ and $p-i k B$ expression, indicating that it interfered with the NF-kB pathway by inhibiting TNF- $\alpha$-induced degradative phosphorylation of $i \kappa B$, an inhibitor of NF- $k B$, which binds to the transcription factor in the cytosol, thereby preventing its translocation to the nucleus [32]. The current results showed that ARE at $120 \mu \mathrm{g} / \mathrm{ml}$ could completely inhibit TNF- $\alpha$-induced NF- $\mathrm{kB}$ nuclear translocation. Selective inhibition of NF- $\kappa B$ activation by ARE would therefore affect 
VCAM-1 and ICAM-1 preferentially. We demonstrated that ARE regulated VCAM-1 and ICAM-1 expression levels through down-regulation of the NF- $\mathrm{kB}$ pathway in SVEC cells.

To further elucidate the impact of ARE on atherosclerosis, we investigated its effects in $\mathrm{apoE}^{-/-}$mice fed on an atherogenic diet. ApoE ${ }^{-1-}$ mice are created by targeted gene inactivation, and are considered to be a relevant model for atherosclerosis because they are hypercholesterolemic and develop spontaneous arterial lesions [33]. $\mathrm{ApoE}^{-/-}$mice treated with ARE had significantly smaller aortic sinus lesions, lower numbers of macrophages in the aortic wall, and decreased expression levels of adhesion molecules (VCAM-1 and ICAM-1) in the vessel wall compared with control mice. In conclusion, ARE could prevent the formation of atherosclerosis by regulating the expression of adhesion molecules in aortas of $\mathrm{apoE}^{-/-}$mice.

\section{Conclusions}

In conclusion, the results of this study demonstrate that ARE has the capacity to protect the aorta from atherosclerosis, potentially via an anti-inflammatory mechanism. To the best of our knowledge, this is the first study to reveal a possible role for ARE in the treatment of atherosclerosis. One of the major mechanisms of ARE action appears to be through regulating the levels of adhesion molecule expression in endothelial cells via the NF- $\mathrm{KB}$ pathway. These findings suggest an anti-atherosclerotic effect of ARE and support its potential clinical use for the treatment of atherosclerosis.

\section{Competing interests}

The authors declare that they have no competing interests.

\section{Acknowledgments}

This work was supported by grants from the China National Science Foundation (81130072, 81100076, 30971218 and 81070097).

\section{Author details \\ 'Department of Cardiology, Cardiovascular Research Institute, Shenyang Northern Hospital, Shenyang, China. ${ }^{2}$ The Affiliated Hospital of Liaoning University of TCM, Shenyang, China. ${ }^{3}$ Dalian Institute of Chemical Physics, Chinese Academy of Sciences, Dalian, China. ${ }^{4}$ Department of Cardiology, Shenyang General Hospital, 83 Wenhua Road, Shenyang 110840, China.}

\section{Authors' contributions}

YY was responsible for performing the experiments, analyzing data and drafting the manuscript. YD and SL participated in the analysis of data. $X Z^{c}$ and JF extracted Astragali Radix extract. CY, XZ ${ }^{\mathrm{a}}$ and $\mathrm{YH}$ supervised the whole study and revised the manuscript. All authors have read and approved the final manuscript.

Received: 20 December 2011 Accepted: 26 April 2012

Published: 26 April 2012

\section{References}

1. Ross R: Atherosclerosis-an inflammatory disease. N Engl J Med 1999, 340(2):115-126.
2. Carlos TM, Harlan JM: Leukocyte-endothelial adhesion molecules. Blood 1994, 84(7):2068-2101.

3. Rothlein R, Dustin ML, Marlin SD, Springer TA: A human intercellular adhesion molecule (ICAM-1) distinct from LFA-1. J Immunol 1986, 137(4):1270-1274.

4. Montefort S, Gratziou C, Goulding D, Polosa R, Haskard DO, Howarth PH, Holgate ST, Carroll MP: Bronchial biopsy evidence for leukocyte infiltration and upregulation of leukocyte-endothelial cell adhesion molecules 6 hours after local allergen challenge of sensitized asthmatic airways. J Clin Invest 1994, 93(4):1411-1421.

5. Soliman A, Kee P: Experimental models investigating the inflammatory basis of atherosclerosis. Curr Atheroscler Rep 2008, 10(3):260-271.

6. Preiss DJ, Sattar N: Vascular cell adhesion molecule-1: a viable therapeutic target for atherosclerosis?. Int J Clin Pract 2007, 61(4):697-701.

7. Li M, Zhang Y, Ren H, Zhu X: Effect of clopidogrel on the inflammatory progression of early atherosclerosis in rabbits model. Atherosclerosis 2007, 194(2):348-356.

8. You H, Lu Y, Gui D, Peng A, Chen J, Gu Y: Aqueous extract of Astragali Radix ameliorates proteinuria in adriamycin nephropathy rats through inhibition of oxidative stress and endothelial nitric oxide synthase. $J$ Ethnopharmacol 2011, 134(1):176-182.

9. Zhao P, Su G, Xiao X, Hao E, Zhu X, Ren J: Chinese medicinal herb Radix Astragali suppresses cardiac contractile dysfunction and inflammation in a rat model of autoimmune myocarditis. Toxicol Lett 2008, 182(1-3):29-35.

10. Han DO, Lee HJ, Hahm DH: Wound-healing activity of Astragali Radix in rats. Methods Find Exp Clin Pharmacol 2009, 31(2):95-100.

11. Shon $\mathrm{YH}, \mathrm{Nam} \mathrm{KS}$ : Protective effect of Astragali radix extract on interleukin 1beta-induced in $\mathrm{fl}$ ammation in human amnion. Phytother Res 2003, 17(9):1016-1020.

12. Ryu M, Kim EH, Chun M, Kang S, Shim B, Yu YB, Jeong G, Lee JS: Astragali Radix elicits anti-inflammation via activation of MKP-1, concomitant with attenuation of p38 and Erk. J Ethnopharmacol 2008, 115(2):184-193.

13. Majewska I, Gendaszewska-Darmach E: Proangiogenic activity of plant extracts in accelerating wound healing - a new face of old phytomedicines. Acta Biochim Pol. Epub ahead of print.

14. Shon $\mathrm{YH}, \mathrm{Kim} J \mathrm{H}, \mathrm{Nam} \mathrm{KS}$ : Effect of Astragali radix extract on lipopolysaccharide-induced inflammation in human amnion. Biol Pharm Bull 2002, 25(1):77-80.

15. Lee YS, Han OK, Park CW, Yang CH, Jeon TW, Yoo WK, Kim SH, Kim HJ: Pro-inflammatory cytokine gene expression and nitric oxide regulation of aqueous extracted Astragali radix in RAW 264.7 macrophage cells. J Ethnopharmacol 2005, 100(3):289-294.

16. Xu Y, Feng L, Wang S, Zhu Q, Zheng Z, Xiang P, He B, Tang D: Calycosin protects HUVECs from advanced glycation end products-induced macrophage infiltration. J Ethnopharmacol 2011, 137(1):359-370.

17. Zhang WJ, Hufnagl P, Binder BR, Wojta J: Antiinflammatory activity of astragaloside IV is mediated by inhibition of NF-kappaB activation and adhesion molecule expression. Thromb Haemost 2003, 90(5):904-914.

18. Chen J, Gui D, Chen Y, Mou L, Liu Y, Huang J: Astragaloside IV improves high glucose-induced podocyte adhesion dysfunction via alpha3beta1 integrin upregulation and integrin-linked kinase inhibition. Biochem Pharmacol 2008, 76(6):796-804.

19. Chao CY, Lii CK, Tsai IT, Li CC, Liu KL, Tsai CW, Chen HW: Andrographolide inhibits ICAM-1 expression and NF-kappaB activation in TNF-alphatreated EA.hy926 cells. J Agric Food Chem 2011, 59(10):5263-5271.

20. Chen XJ, Bian ZP, Lu S, Xu JD, Gu CR, Yang D, Zhang JN: Cardiac protective effect of Astragalus on viral myocarditis mice: comparison with Perindopril. Am J Chin Med 2006, 34(3):493-502.

21. Xu XL, Ji H, Gu SY, Shao Q, Huang QJ, Cheng YP: Cardioprotective effects of Astragali Radix against isoproterenol-induced myocardial injury in rats and its possible mechanism. Phytother Res 2008, 22(3):389-394.

22. Zhao KS, Mancini C, Doria G: Enhancement of the immune response in mice by Astragalus membranaceus extracts. Immunopharmacology 1990, 20(3):225-233.

23. van Gils JM, Zwaginga JJ, Hordijk PL: Molecular and functional interactions among monocytes, platelets, and endothelial cells and their relevance for cardiovascular diseases. J Leukoc Biol 2009, 85(2):195-204.

24. Sprague $A H$, Khalil RA: Inflammatory cytokines in vascular dysfunction and vascular disease. Biochem Pharmacol 2009, 78(6):539-552.

25. Deng $Y H$, Alex D, Huang HQ, Wang N, Yu N, Wang YT, Leung GP, Lee SM: Inhibition of TNF-alpha-mediated endothelial cell-monocyte cell adhesion 
and adhesion molecules expression by the resveratrol derivative, trans-3,5,4'-trimethoxystilbene. Phytother Res 2011, 25(3):451-457.

26. Maekawa Y, Ishikawa K, Yasuda O, Oguro R, Hanasaki H, Kida I, Takemura Y, Ohishi M, Katsuya T, Rakugi H: Klotho suppresses TNF-alpha-induced expression of adhesion molecules in the endothelium and attenuates NF-kappaB activation. Endocrine 2009, 35(3):341-346.

27. Kanters E, Pasparakis M, Gijbels MJ, Vergouwe MN, Partouns-Hendriks I, Fijneman RJ, Clausen BE, Forster I, Kockx MM, Rajewsky K, et al: Inhibition of NF-kappaB activation in macrophages increases atherosclerosis in LDL receptor-deficient mice. J Clin Invest 2003, 112(8):1176-1185.

28. Cuaz-Perolin C, Billiet L, Bauge E, Copin C, Scott-Algara D, Genze F, Buchele B, Syrovets T, Simmet T, Rouis M: Antiinflammatory and antiatherogenic effects of the NF-kappaB inhibitor acetyl-11-keto-beta-boswellic acid in LPS-challenged ApoE-/- mice. Arterioscler Thromb Vasc Biol 2008, 28(2):272-277.

29. Yao R, Cheng X, Liao YH, Chen Y, Xie JJ, Yu X, Ding YJ, Tang T: Molecular mechanisms of felodipine suppressing atherosclerosis in high-cholesterol-diet apolipoprotein E-knockout mice. J Cardiovasc Pharmacol 2008, 51(2):188-195.

30. Altman R, Motton DD, Kota RS, Rutledge JC: Inhibition of vascular inflammation by dehydroepiandrosterone sulfate in human aortic endothelial cells: roles of PPARalpha and NF-kappaB. Vascul Pharmacol 2008, 48(2-3):76-84.

31. Shibata Y, Kume N, Arai H, Hayashida K, Inui-Hayashida A, Minami M, Mukai E, Toyohara M, Harauma A, Murayama T, et al: Mulberry leaf aqueous fractions inhibit TNF-alpha-induced nuclear factor kappaB (NF-kappaB) activation and lectin-like oxidized LDL receptor-1 (LOX-1) expression in vascular endothelial cells. Atherosclerosis 2007, 193(1):20-27.

32. Delerive P, Gervois P, Fruchart JC, Staels B: Induction of IkappaBalpha expression as a mechanism contributing to the anti-inflammatory activities of peroxisome proliferator-activated receptor-alpha activators. $J$ Biol Chem 2000, 275(47):36703-36707.

33. Nakashima Y, Plump AS, Raines EW, Breslow JL, Ross R: ApoE-deficient mice develop lesions of all phases of atherosclerosis throughout the arterial tree. Arterioscler Thromb 1994, 14(1):133-140

doi:10.1186/1472-6882-12-54

Cite this article as: You et al:: Anti-atherosclerotic function of Astragali Radix extract: downregulation of adhesion molecules in vitro and in vivo. BMC Complementary and Alternative Medicine 2012 12:54.

\section{Submit your next manuscript to BioMed Central and take full advantage of:}

- Convenient online submission

- Thorough peer review

- No space constraints or color figure charges

- Immediate publication on acceptance

- Inclusion in PubMed, CAS, Scopus and Google Scholar

- Research which is freely available for redistribution 